Review

\title{
Gene Silencing in Crustaceans: From Basic Research to Biotechnologies
}

\author{
Amir Sagi ${ }^{1, *}$, Rivka Manor ${ }^{1}$ and Tomer Ventura ${ }^{2}$ \\ 1 Department of Life Sciences and the National Institute for Biotechnology in the Negev, \\ Ben-Gurion University, P.O. Box 653, Beer Sheva 84105, Israel; E-Mail: mnor@bgu.ac.il \\ 2 Faculty of Science, Health, Education and Engineering, GeneCology Research Centre, \\ University of the Sunshine Coast, 4 Locked Bag, Maroochydore, Queensland 4558, Australia; \\ E-Mail: tventura@usc.edu.au
}

* Author to whom correspondence should be addressed; E-Mail: sagia@bgu.ac.il; Tel.: +972-8-646-1364; Fax: +972-8-647-9062.

Received: 17 May 2013; in revised form: 14 August 2013 / Accepted: 8 October 2013 /

Published: 7 November 2013

\begin{abstract}
Gene silencing through RNA interference (RNAi) is gaining momentum for crustaceans, both in basic research and for commercial development. RNAi has proven instrumental in a growing number of crustacean species, revealing the functionality of novel crustacean genes essential among others to development, growth, metabolism and reproduction. Extensive studies have also been done on silencing of viral transcripts in crustaceans, contributing to the understanding of the defense mechanisms of crustaceans and strategies employed by viruses to overcome these. The first practical use of gene silencing in aquaculture industry has been recently achieved, through manipulation of a crustacean insulin-like androgenic gland hormone. This review summarizes the advancements in the use of RNAi in crustaceans, and assesses the advantages of this method, as well as the current hurdles that hinder its large-scale practice.
\end{abstract}

Keywords: crustaceans; gene function; RNA interference; humoral defense mechanisms; androgenic gland; insulin-like peptide; biotechnology 


\section{Gene Silencing is Gaining Momentum in Crustaceans}

In 1998, Fire and colleagues [1] were the first to reveal the induction of RNA interference (RNAi) by exogenous application of double-stranded RNA (dsRNA) in a metazoan species. This work has since revolutionized the field of molecular genetics, prompting a plethora of studies applying dsRNA for gene knock-down studies through RNAi in a variety of metazoan species [2], leading to the awarding of Andrew Z. Fire and Craig C. Mello with the Nobel Prize in Physiology or Medicine in 2006 [3]. RNAi is an endogenous mechanism for highly specific post transcriptional silencing of gene expression. The active components, small interfering RNAs (siRNAs) are generated endogenously to moderate gene activity, but can be generated by exogenous administration of siRNAs, short hairpin-loop RNAs (shRNAs) or long dsRNA that is cleaved into siRNAs by an enzyme called Dicer. These siRNAs then serve as a sequence specific locator of the target RNA as part of the endonuclease activity of the RNA-induced silencing complex (RISC) [4-6]. Up until 2005, only a handful of pioneering reports had evaluated the use of RNAi in crustaceans [7-11]. These preceded a few dozen other published studies within the following eight years, most reporting the exogenous application of dsRNA. It is thus evident that RNAi-based research in crustaceans is gaining momentum, and is becoming an integral scientific component for rapid and reliable study of crustacean gene functions. RNAi enables transient knock-down of specific gene expression, without the need to genetically modify the studied organisms. In comparison to in vivo studies applying RNAi in model organisms [12], this field is still in its infancy in crustaceans, perhaps owing to the fact that the administration methods (lack of oral administration, referred to in Section 3.3) have not reached a stage where large-scale studies are optional. As next generation sequencing technologies become more affordable and more commonly used, it is estimated that crustaceans will not lag far behind model organisms, for which genomic data availability simplifies tailoring of siRNAs and multi-gene research approach is feasible.

Crustacea is a large ( 67,000 known species) and diverse Subphylum of arthropods [13], populating various niches ranging from terrestrial to marine, from flourishing tidal zones to extremely harsh and low populated environments such as thermal vents. Due to their extremely wide dispersal they serve as model organisms to monitor toxicity [14] and environmental changes [15], while on the other hand, their hardiness and adaptability place them among the worst known invasive species [16,17]. Crustaceans are considered ancestral to insects $[18,19]$ and are thus an important group for arthropod evolution studies. Many crustacean species, primarily from the order Decapoda, are commercially important for human consumption [16], while the entire aquaculture industry heavily relies on stable, continuous supply of but a few branchiopod crustacean (i.e., Artemia) species [20].

Most RNAi studies in crustaceans performed to date were on commercially important decapod species, and will be elaborately discussed in this review. However, the employment of crustacean model organisms - such as the branchiopod Daphnia pulex, whose genome was fully sequenced and annotated [21] — might change this trend.

In crustaceans, dsRNA injections have proven to be the most efficient method for RNAi induction. Although this injection-based methodology was found to be successful in the laboratory, in order to enable rapid, large-scale RNAi experiments, other delivery techniques must be devised. One such large-scale administration method of RNAi is used in the plathyhelminth Caenorhabditis elegans, where feeding with dsRNA-producing bacteria proved to be effective [22]. Unlike the time-consuming 
and laborious injections that are sometimes confined by the size of the organism, the option of RNAi administration via feeding could potentially be applied for manipulating a wide array of genes in many individuals at the same time. Attempts to devise a more efficient administration method were made primarily in the context of anti-viral defense in crustaceans and this is thus discussed as part of the section dedicated to this subject (Sections 3.2 and 3.3).

Solving the delivery hurdle might be achieved by suggested methods described for other organisms [23]. A case study of RNAi biotechnology application in aquaculture is given in Section 4, delineating how prawn monosex populations were generated for the first time through RNAi-based biotechnology at a large scale aquaculture industry. Other plausible applications for RNAi in aquaculture of crustaceans might be for the control and synchronization of the molt cycle, eradication of invasive species and immune defense.

\section{Understanding the Functionality of Novel Crustacean Genes through Gene Silencing}

Gene silencing has contributed to our understanding of the functionality of novel crustacean genes with importance to development, growth, metabolism and reproduction, including genes encoding structural exoskeletal proteins, eyestalk neuropeptides and receptors. This section reviews studies that have used RNAi for this purpose (not including viral-related genes, which will be discussed in Section 3). The list of functional genomic cases reviewed in this section is summarized in Table 1.

\subsection{Genes Related to Biomineralization}

Biomineralization in crustaceans plays a key role in calcium metabolism during molting: the periodic shedding and replacement of the exoskeleton. Several crustacean species form temporary extracellular calcium carbonate storage deposits during the premolt stage [24]. In freshwater crayfish, including the Australian red-claw crayfish Cherax quadricarinatus, these deposits are in the form of a pair of disc-like structures, known as gastroliths, which are located on either side of the stomach wall $[25,26]$. Recently, the role of two gastrolith proteins (GAPs) in C. quadricarinatus, GAP 65 and GAP 10, in the development of gastroliths was demonstrated using dsRNA injections. GAP 65, which was extracted from late premolt gastroliths of C. quadricarinatus, is a calcium-binding glycoprotein, predicted to bind chitin. In a functional assay of GAP 65, this protein was suggested to play a dual role. Using dsRNA to silence the gene encoding GAP 65 in vivo demonstrated its involvement in both the construction of extracellular matrix and deposition of calcium. In this study irregularities in gastrolith morphologies were manifested following the knockdown of GAP 65 [27]. Silencing of GAP 10 in vivo resulted in a prolonged premolt stage and in the development of gastroliths with irregularly rough surfaces. These findings suggest that GAP 10 may be involved in the assembly of the gastrolith chitin-protein-mineral complex, particularly in the deposition of amorphous calcium carbonate [28]. These two studies demonstrate how within a relatively short period, functionality of newly discovered genes can be assessed using RNAi, unveiling different aspects in the assembly of a previously over-looked organ. 
Table 1. Study of novel crustacean genes using RNA interference (RNAi).

\begin{tabular}{|c|c|c|c|c|c|c|}
\hline Field of Research & $\begin{array}{l}\text { RNAi administration } \\
\text { method }\end{array}$ & Model Organinsm & Order & Year & Authors & Title \\
\hline Biominerology & dsRNA injection & Cherax quadricarinatus & Decapoda & 2008 & Shechter et al. & $\begin{array}{l}\text { A gastrolith protein serving a dual role in the formation of } \\
\text { an amorphous mineral containing extracellular matrix }\end{array}$ \\
\hline Biominerology & dsRNA injection & Cherax quadricarinatus & Decapoda & 2010 & Glazer et al. & A protein involved in the assembly of an extracellular calcium storage matrix \\
\hline Development/differentiation & dsRNA injection & Artemia franciscana & Anostraca & 2006 & Copf et al. & $\begin{array}{l}\text { Knockdown of spalt function by RNAi causes de-repression of } \\
\text { Hox genes and homeotic transformations in the crustacean Artemia franciscana }\end{array}$ \\
\hline Development/differentiation & $\begin{array}{l}\text { Chemicaly modified } \\
\text { siRNA oligo injection }\end{array}$ & Parhyale Ultrabithorax & Amphipoda & 2009 & Liubicich et al. & $\begin{array}{l}\text { Knockdown of Parhyale Ultrabithorax recapitulates evolutionary changes in crustacean } \\
\text { appendage morphology }\end{array}$ \\
\hline Development/differentiation & dsRNA injection & Daphnia magna & Cladocera & 2011 & Kato et al. & $\begin{array}{l}\text { Development of an RNA interference method in the cladoceran crustacean } \\
\text { Daphnia magna }\end{array}$ \\
\hline Development/differentiation & dsRNA injection & Litopenaeus vannamei & Decapoda & 2008 & Hui et al. & $\begin{array}{l}\text { Characterization of the putative farnesoic acid } O \text {-methyltransferase (LvFAMeT) cDNA } \\
\text { from white shrimp, Litopenaeus vannamei: Evidence for its role in molting }\end{array}$ \\
\hline Metabolism & dsRNA injection & Litopenaeus vannamei & Decapoda & 2010 & Soñanez-Organis et al. & $\begin{array}{l}\text { Silencing of the hypoxia inducible factor } 1 \text {-HIF-1- obliterates the effects of hypoxia on } \\
\text { glucose and lactate concentrations in a tissue-specific manner in the shrimp } \\
\text { Litopenaeus vannamei }\end{array}$ \\
\hline Growth & dsRNA injection & Penaeus monodon & Decapoda & 2011 & De Santis et al. & $\begin{array}{l}\text { Growing backwards: an inverted role for the shrimp ortholog of vertebrate myostatin and } \\
\text { GDF11 }\end{array}$ \\
\hline Metabolism & dsRNA injection & Procambarus clarkia & Decapoda & 2011 & White et al. & $\begin{array}{l}\text { Characterization of sarcoplasmic calcium binding protein (SCP) variants from freshwater } \\
\text { crayfish Procambarus clarkii }\end{array}$ \\
\hline Metabolism & dsRNA injection & Litopenaeus schmitti & Decapoda & 2006 & Lugo et al. & $\begin{array}{l}\text { Molecular cloning and characterization of the crustacean hyperglycemic hormone cDNA } \\
\text { from Litopenaeus schmitti }\end{array}$ \\
\hline Reproduction & dsRNA injection & Metapenaeus ensis & Decapoda & 2007 & Tiu and Chan & $\begin{array}{l}\text { The use of recombinant protein and RNA interference approaches to study the } \\
\text { reproductive functions of a gonad-stimulating hormone from the shrimp } \\
\text { Metapenaeus ensis }\end{array}$ \\
\hline Molt & dsRNA injection & Cherax quadricarinatus & Decapoda & 2012 & Pamuru et al. & $\begin{array}{l}\text { Stimulation of molt by RNA interference of the molt-inhibiting } \\
\text { hormone in the crayfish Cherax quadricarinatus }\end{array}$ \\
\hline Osmo-regulation & dsRNA injection & Litopenaeus vannamei & Decapoda & 2007 & Tiu et al. & $\begin{array}{l}\text { The LvCHH-ITP gene of the shrimp (Litopenaeus vannamei) produces a widely } \\
\text { expressed putative ion transport peptide (LvITP) for osmo-regulation }\end{array}$ \\
\hline Reproduction & $\begin{array}{l}\text { dsRNA in tissue } \\
\text { culture }\end{array}$ & Penaeus monodon & Decapoda & 2008 & Treerattrakool et al. & $\begin{array}{l}\text { Molecular characterization of gonad-inhibiting hormone of Penaeus monodon and } \\
\text { elucidation of its inhibitory role in vitellogenin expression by RNA interference }\end{array}$ \\
\hline Reproduction & dsRNA injection & Penaeus monodon & Decapoda & 2011 & Treerattrakool et al. & $\begin{array}{l}\text { Induction of Ovarian Maturation and Spawning in Penaeus monodon Broodstock by } \\
\text { Double-Stranded RNA }\end{array}$ \\
\hline
\end{tabular}


Table 1. Cont.

\begin{tabular}{|c|c|c|c|c|c|c|}
\hline Field of Research & $\begin{array}{l}\text { RNAi administration } \\
\text { method }\end{array}$ & Model Organinsm & Order & Year & Authors & Title \\
\hline Reproduction & $\begin{array}{l}\text { Feeding with dsRNA } \\
\text { enriched Artemia }\end{array}$ & Penaeus monodon & Decapoda & 2013 & Treerattrakool et al. & $\begin{array}{l}\text { Silencing of gonad-inhibiting hormone gene expression in Penaeus monodon by feeding } \\
\text { with GIH dsRNA enriched Artemia }\end{array}$ \\
\hline Reproduction & dsRNA injection & Penaeus monodon & Decapoda & 2011 & Sathapondecha et al. & $\begin{array}{l}\text { Potential roles of transglutaminase and thioredoxin in the release of gonad-stimulating } \\
\text { factor in Penaeus monodon: Implication from differential expression in the brain during } \\
\text { ovarian maturation cycle }\end{array}$ \\
\hline Growth & dsRNA injection & $\begin{array}{l}\text { Macrobrachium } \\
\text { rosenbergii }\end{array}$ & Decapoda & 2013 & Sharabi et al. & $\begin{array}{l}\text { Dual function of a putative epidermal growth factor receptor in the decapod crustacean } \\
\text { Macrobrachium rosenbergii }\end{array}$ \\
\hline Reproduction & dsRNA injection & Penaeus monodon & Decapoda & 2008 & Tiu et al. & $\begin{array}{l}\text { From hepatopancreas to ovary: molecular characterization of a shrimp vitellogenin } \\
\text { receptor involved in the processing of vitellogenin }\end{array}$ \\
\hline Molt & dsRNA injection & $\begin{array}{l}\text { Fenneropenaeus } \\
\text { chinensis }\end{array}$ & Decapoda & 2009 & Priya et al. & $\begin{array}{l}\text { Molecular characterization and effect of RNA interference of retinoid X receptor (RXR) } \\
\text { on E75 and chitinase gene expression in Chinese shrimp Fenneropenaeus chinensis }\end{array}$ \\
\hline Molt & dsRNA injection & $\begin{array}{l}\text { Fenneropenaeus } \\
\text { chinensis }\end{array}$ & Decapoda & 2010 & Priya et al. & $\begin{array}{l}\text { Molecular characterization of an ecdysone inducible gene E75 of Chinese shrimp } \\
\text { Fenneropenaeus chinensis and elucidation of its role in molting by RNA interference }\end{array}$ \\
\hline Organ regeneration & dsRNA injection & Uca pugilator & Decapoda & 2013 & Das and Durica & $\begin{array}{l}\text { Ecdysteroid receptor signaling disruption obstructs blastemal cell proliferation during } \\
\text { limb regeneration in the fiddler crab, Uca pugilator }\end{array}$ \\
\hline Reproduction & dsRNA injection & Carcinus maenas & Decapoda & 2011 & Nagaraju et al. & $\begin{array}{l}\text { Molecular cloning and sequence of retinoid } \mathrm{X} \text { receptor in the green crab Carcinus } \\
\text { maenas: a possible role in female reproduction }\end{array}$ \\
\hline Sexual differentiation & dsRNA injection & Daphnia magna & Cladocera & 2011 & Kato et al. & $\begin{array}{l}\text { Environmental sex determination in the branchiopod crustacean Daphnia magna: deep } \\
\text { conservation of a Doublesex gene in the sex-determining pathway }\end{array}$ \\
\hline Sexual differentiation & dsRNA injection & Cherax quadricarinatus & Decapoda & 2012 & Rosen et al. & $\begin{array}{l}\text { A sexual shift induced by silencing of a single insulin-like gene in crayfish: ovarian } \\
\text { upregulation and testicular degeneration }\end{array}$ \\
\hline Sexual differentiation & dsRNA injection & $\begin{array}{l}\text { Macrobrachium } \\
\text { rosenbergii }\end{array}$ & Decapoda & 2009 & Ventura et al. & $\begin{array}{l}\text { Temporal silencing of an androgenic gland-specific insulin-like gene affecting } \\
\text { phenotypic gender differences and spermatogenesis }\end{array}$ \\
\hline Sexual differentiation & dsRNA injection & $\begin{array}{l}\text { Macrobrachium } \\
\text { rosenbergii }\end{array}$ & Decapoda & 2012 & Ventura et al. & $\begin{array}{l}\text { Timing sexual differentiation full functional sex seversal achieved through silencing of a } \\
\text { single insulin like gene in the prawn Macrobrachium rosenbergii }\end{array}$ \\
\hline RNAi & dsRNA injection & Penaeus monodon & Decapoda & 2008 & Dechklar et al. & $\begin{array}{l}\text { Characterization of Argonaute cDNA from Penaeus monodon and implication of its role } \\
\text { in RNA interference }\end{array}$ \\
\hline RNAi & dsRNA injection & $\begin{array}{l}\text { Marsupenaeus } \\
\text { japonicus }\end{array}$ & Decapoda & 2012 & Wang et al. & $\begin{array}{l}\text { TRBP and eIF6 Homologue in Marsupenaeus japonicus Play Crucial Roles in Antiviral } \\
\text { Response }\end{array}$ \\
\hline
\end{tabular}




\subsection{Genes Related to Development, Differentiation and Metabolism}

Hox genes specify segmental identities and organ patterning in arthropods by forming a gradient of expression along body axes during embryo development [29]. Spalt genes are associated with Hox gene function, with varied association in diverse species, acting as cofactors, regulators or targets of different Hox paralogues. Copf et al. [30] studied the role of Spalt in the branchiopod crustacean Artemia franciscana. Using RNAi, they showed that knocking down Spalt expression results in various segmental anomalies. Based on the silencing phenotypes, combined with the spatial-temporal expression pattern of Spalt and prior knowledge of Hox genes, the authors suggested that Spalt acts as a repressor of Hox gene expression in A. franciscana where unleashing the expression of Hox genes in an uncontrolled pattern, through Spalt silencing, generates stochastic aberrations of segmentation.

In another study, the Hox gene Ultrabithorax ( $U b x$, [31]) was shown to regulate the number of maxillipeds in the amphipod Parhyale hawaiensis. Reduction of Ubx expression via siRNA injections, led to a phenotype of additional maxillipeds, which persisted in adults, supporting the key role of Ubx in defining crustacean appendage boundaries. Since the new morphological pattern was similar to that seen in other crustacean species, this alteration was interpreted as an insight into the mechanism of morphological evolution [31]. One plausible approach to challenge this hypothesis would be to compare the expression and function of $U b x$ in association with the number of maxillipeds in different taxonomic groups of crustaceans. The expression pattern of $U b x$ might indeed correlate with morphological pattern of maxillipeds in crustaceans. Another gene related to appendage development in invertebrates and vertebrates is the Distal-less $(D l l)$ gene. Kato et al. [32] established a technique to inject dsRNA into ovulated eggs of the cladoceran crustacean D. magna. Injection of $D l l$-specific dsRNA led to Dll mRNA degradation. Two dsRNA constructs targeting different regions of the DII gene were administered. Although the survival rates observed were different between the two constructs, the same phenotype of truncated second antenna was observed using these two constructs, suggesting the specific effect of Dll RNAi in D. magna. In this study, phenotypes of Dll RNAi were found to be dose dependent, suggesting that necessary amounts of Dll vary depending on the appendages, organs, and substructure-forming regions.

Methyl farnesoate (MF), the crustacean homolog of the insect juvenile hormone, regulates metamorphosis and is also implicated in the regulation of growth and reproduction in crustaceans [33,34]. Farnesoic acid $O$-methyltransferase (FAMeT) is a key enzyme in MF formation, converting farnesoic acid (FA) to MF. To study the function of this gene in L. vannamei ( $L v F A M e T)$ during molting, Hui et al. [35] knocked down the expression of $L v F A M e T$ in shrimp using dsRNA injections, preventing treated individuals from advancing to the final stage of the molt cycle and disrupting the expression of the molt-related genes encoding cathepsin-L and hemocyanin. Subsequently, 100\% mortality of the treated individuals was observed (same as in silencing of the ecdysteroid receptor (EcR) primary target FcE75), with no death in the control group that was injected with an exogenous non-targeting dsRNA. These results demonstrate that conversion of FA to MF has a crucial role in growth and regulation of molting.

Hypoxia inducible factor 1 (HIF-1) is a transcription factor, which regulates many molecular and physiological responses to hypoxia [36]. HIF-1 is a heterodimer composed of $\alpha$ and $\beta$ subunits. In a study by Soñanez-Organis et al. [37], dsRNA injections targeting HIF-1 ( $\alpha$ or $\beta$ subunit separately) into L. vannamei effectively reduced the transcript levels in gills but not in muscle of shrimp 
maintained under normoxia and hypoxia. Silencing of either $\alpha$ or $\beta$ subunits affected the concentrations of glucose and lactate (the substrate and end-product of anaerobic glycolysis respectively) in the hemolymph and gills of shrimps exposed to hypoxic conditions (compared to glucose and lactate levels in the control group), suggesting that a metabolic shift is induced by HIF-1 in response to hypoxia.

Myostatin (MSTN) and GDF11 are closely related members of the transforming growth factor- $\beta$ (TGF- $\beta$ ) superfamily. This gene was identified in $P$. monodon and its specific function in the regulation of growth was studied through RNAi [38]. In this study Luciferase-dsRNA (Luc-dsRNA) was used as an exogenous down-regulation control and $\beta$-actin-dsRNA was used as an experimental technique control. The pmMstn/Gdf11 gene was down-regulated by tail-muscle injection of sequence-specific dsRNAs. Approximately 40\% down-regulation of endogenous pmMstn/Gdf11 expression was achieved. Positive control animals injected with $\beta$-actin-dsRNA died within 2-4 days post-injection, indicating that endogenous gene silencing using tail-muscle injection of dsRNA was successful. Shrimp injected with $p m M s t n / G d f 11$-dsRNA exhibited a slower growth rate compared with $L u c-d s R N A$ - and saline-injected controls. This response is opposite to that seen in higher vertebrates, suggesting that this gene is a positive growth regulator in P. monodon [38].

Sarcoplasmic calcium binding protein $(\mathrm{SCP})$ is an invertebrate calcium buffering protein that interacts with two to three calcium ions [39]. White et al. identified three SCP variants in the freshwater crayfish Procambarus clarkii (termed pcSCP1a-c) [40]. Knockdown of pcSCP1 by dsRNA injections, decreased $S C P$ expression by about $50 \%$. The pcSCPla dsRNA that was injected affected the expression of all three $p c S C P 1$ variants due to sequence similarity to all three, on either side of the variable region. Negative controls were injected with saline or with a $1.85 \mathrm{~kb}$ dsRNA from Xenopus elongation factor $1 \propto$ gene. Crayfish injected with $S C P$-dsRNA were substantially less active than control animals due to a reduction in their muscular activity.

\subsection{Genes Encoding Eyestalk Neuropeptides}

The decapod eyestalk Crustacean Hyperglycemic Hormone (CHH)/Molt Inhibiting Hormone (MIH)/Gonad inhibiting Hormone (GIH) family of neuropeptides is known to regulate important processes such as glucose metabolism, molting and reproduction. $\mathrm{CHH}$ neuropeptides were initially detected in the eyestalk X-organ sinus gland neuroendocrine complex (XOSG) [41,42]. Their function was demonstrated in several studies using gene silencing approaches. The first study to report silencing of a decapod-derived neuropeptide was published by Lugo et al., applying RNAi in the shrimp Litopenaeus schmitti [43], investigating whether RNAi can inhibit $\mathrm{CHH}$ function. Injection of $\mathrm{CHH}$ dsRNA into the abdominal hemolymph sinuses resulted in undetectable $C H H$ mRNA levels within $24 \mathrm{~h}$ and a corresponding decrease in hemolymph glucose levels, suggesting that functional gene silencing had occurred. These findings were followed by Tiu and Chan [44] who demonstrated the gonad stimulatory function of the molt-inhibiting hormone (MeMIH-B) in Metapenaeus ensis by applying RNAi. The gonad stimulatory function of MeMIH-B was demonstrated by a decline of vitellogenin ( $\mathrm{Vg}$, the precursor of the major yolk protein Vitellin) gene expression in the hepatopancreas and ovary in the MeMIH-B silenced shrimps, reflecting a wider phenomenon of multifunctionality in the $\mathrm{CHH}$ superfamily [45]. 
The role of $\mathrm{MIH}$ in regulating molting in the $C$. quadricarinatus was recently demonstrated by RNAi. In vivo injections of $C$. quadricarinatus $M I H$ dsRNA resulted in, additionally to eyestalk ablation, acceleration of molt cycles. This acceleration was reflected by a significant reduction (up to $32 \%)$ in molt intervals and an increase in molt mineralization index (MMI), which correlated with the induction of ecdysteroid hormones [46].

Tiu et al. [47] also identified a CHH-like gene in the white shrimp L. vannamei, which functions as an ion transport peptide (thus termed LvCHH-ITP). Silencing of LvCHH-ITP provided molecular evidence to support its osmo-regulatory function. Shrimp injected with high concentration of dsRNA targeting $L v C H H$-ITP died within $24 \mathrm{~h}$. However, no control dsRNA was used to determine whether the death of the animals was caused by LvCHH-ITP down-regulation or due to a nonspecific toxic effect of the dsRNA.

A study by Treerattrakool et al. [48] provided further support towards the function of GIH in the tiger shrimp P. monodon. These authors showed that injections of P. monodon GIH dsRNA, decrease its transcript levels both in eyestalk ganglia and abdominal nerve cord explant culture and in female $P$. monodon. GIH transcript decrease was followed by a precipitous increase in $V g$ transcript level in the ovary of $G I H$-knocked down shrimp individuals, lending support towards the suggested role of GIH as a gonad-inhibiting hormone. In a following study Treerattrakool et al. [49] suggested that GIH-dsRNA could be used as an alternative method to induce ovarian maturation in female P. monodon broodstock, instead of the accepted method of unilateral eyestalk ablation. In a recent study Treerattrakool et al. [50] further explored an oral delivery method for GIH silencing (see Section 3.3 and Table 2). However, expression levels of $G I H$ in the shrimp fed with $G I H$ dsRNA $(72 \%)$ in comparison with dsRNA injection (32\%) showed that oral administration was significantly less effective. Sathapondecha et al. [51] studied the effect of $d s-G I H$ on the expression of other genes in P. monodon. Among the genes that were found to be up regulated in the $d s-G I H$ injected females were thioredoxin and transglutaminase. The expression of the both latter genes was strongly up-regulated in the brains of early-vitellogenic $d s-G I H$ treated female shrimp, suggesting that thioredoxin and transglutaminase are both required for an initial stage of vitellogenesis [51].

\subsection{Receptor-Encoding Genes}

Another group of genes studied through silencing in crustaceans encode for receptors, including the growth-related epidermal growth factor receptor EGFR [52], the reproduction-related $V g$ receptor $(\operatorname{VgR},[53])$ and the molt-related ecdysteroid receptors $(E c R / R X R,[54,55])$. The role of EGFR in the giant freshwater prawn Macrobrachium rosenbergii was revealed by temporarily silencing the transcript through weekly injections of double-stranded EGFR RNA. Such treatment resulted in a significant reduction in growth and a delay in the appearance of a male secondary sexual characteristic, the appendix masculina [52]. EGFR was also found to play a role in eye development. Similar to the effect of EGFR down regulation in insects [56], EGFR-silenced prawns developed abnormal eyes that presented irregular organization of the ommatidia, reflected by unorganized receptor cells occupying large areas of the dioptric portion and by a shortened crystalline tract layer [52]. $V g R$ expression was knocked down in the shrimp P. monodon, leading to a decrease in VgR protein content in the ovary, and an increase in the hemolymph level of $V g$. These results support the hypothesis that in shrimp, $V g$ 
is produced by the hepatopancreas, and is secreted into the hemolymph where it is sequestered into the developing oocytes by $V g R$ through receptor-mediated endocytosis [53].

Retinoid X receptor (RXR) is the heterodimeric partner of ecdysteroid receptor and is required for the molting process of arthropods. In Priya et al. [55] $R X R$ dsRNA was injected into juvenile individuals of the Chinese shrimp Fenneropenaeus chinensis resulting with variation in expression levels of two chitinase genes and of the ecdysone inducible gene FcE75. In arthropods, chitinases degrade chitin to enable partial breakdown of the exoskeleton prior to molting. The products of hydrolysis are ultimately recycled for the synthesis of a new cuticle [57]. Another important ecdysone inducible gene is the EcR/RXR target gene E75, which is one of the primary targets of the ecdysone receptor. A significant reduction in the expression levels of the two chitinase genes and of FcE75 in RXR-silenced shrimp was detected, suggesting involvement of RXR in the downstream regulation of the ecdysone signaling pathway in decapod crustaceans [55]. In a later research, Priya et al. [58] studied the role of FcE75 using the same RNAi technique. FcE75 dsRNA injections efficiently decreased $F c E 75$ transcript levels in juvenile $F$. chinensis in a dose dependent manner and completely arrested molting, eventually leading to mortality. Setogenic analysis of the uropods from molt-arrested shrimp showed defective epidermal retraction and poor development of setae and new cuticle.

Recently, Das and Durica [54] reported that RNAi can be successfully applied in the fiddler crab Uca pugilator to investigate the morphological and physiological consequences of EcR and RXR silencing during limb regeneration. Disrupting $E c R / R X R$ mRNA levels resulted in developmental arrest of growth during early blastemal development and changes in the morphology of limb regeneration. Das and Durica [54] also suggested that RNAi resulted in a systemic effect because contralateral uninjected limbs in experimental animals also exhibited blocked blastemal differentiation. Further strengthening for this notion of a systemic effect came from a significant decrease detected in the ecdysteroid titers in the dsEcR/dsRXR treated crabs and their failure to molt.

In addition to molting, RXR was found to play a role in the reproduction process [59]. Nagaraju et al. studied the role of crab RXR in Carcinus maenas females via silencing of this gene, using ds-GFP as a negative dsRNA control. In this study, the effect of MF was investigated as well. MF was found to stimulate $R X R$ and $V g$ expression levels in vitro and in vivo. Knockdown of $R X R$ transcript levels significantly decreased mRNA levels for $R X R$ and for $V g$ as well as MF levels in hemolymph and OI (percentage of ovarian weight of the total body weight) of green crab. These findings suggest that RXR may be involved in the MF signaling pathway, either by activating EcR under MF regulation, or by direct interaction with MF [59].

\subsection{Genes Related to Sexual Differentiation}

Daphnia magna parthenogenetically produces males in response to environmental signals, rather than the typical genetic sex-specific differentiation common in crustaceans [60]. Still, the conserved gene Doublesex $(D s x)$, which has a crucial role in controlling sexual dimorphism, was found in D. magna. Two Dsx genes have been identified, termed Dsxl and Dsx2. Silencing of Dsxl through dsRNA injections into male embryos resulted in the development of female secondary characteristics and the development of ovaries, while silencing of Dsx2 did not induce the formation of female characteristics. In insects, there are male-specific and female-specific Dsx splice variants, whereas both 
Dsx 1 and Dsx2 share the same sequence in D. magna males and females. The differences might be attributed to expression levels since $D s x l$ is more strongly expressed in males, which could explain the stronger effect of silencing $D s x 1$ compared with $D s x 2$ [60]. In malacostracan crustaceans, male sexual differentiation is controlled by the male-specific androgenic gland (AG) [61]. An AG specific insulin-like gene identified in the red-claw crayfish $C$. quadricarinatus $(C q-I A G)$, was demonstrated via its silencing to have a vast array of effects on sexual differentiation related characteristics [62]. In C. quadricarinatus, sexual plasticity is exhibited by intersex individuals in the form of an active male reproductive system and male secondary sex characters, along with a constantly arrested ovary. Silencing of $C q-I A G$ in intersex individuals induced dramatic sex-related alterations, including male feature feminization, a reduction in sperm production, extensive testicular degeneration, expression of the $V g$ gene, and accumulation of yolk proteins in the developing oocytes. Upon silencing of the gene, AG cells hypertrophied, possibly to compensate for low hormone levels, as reflected by the poor production of the insulin-like hormone (revealed by immunohistochemistry). These results demonstrate both the functionality of $C q-I A G$ as an androgenic hormone-encoding gene and the dependence of male gonad viability on the $C q-I A G$ product.

In $M$. rosenbergii the $\mathrm{AG}$ specific insulin-like hormone (Mr-IAG) was shown to be critical for spermatogenesis and the appearance of external sexual characteristics, through silencing of its transcript in juvenile males [63]. Like in C. quadricarinatus, silencing of $M r-I A G$ led to considerable hypertrophy of the AG, suggesting a similar mode of feedback regulation in these two decapod species. Later it was shown that $M r-I A G$ silencing in early developmental stages can lead to full-functional sex reversal of males into neofemales [64], leading to a pioneering case of RNAi application in aquaculture (see Section 4).

\subsection{Genes Related to RNAi Machinery}

Among the RNAi components that were identified and characterized in crustaceans are Dicer, Argonaute, transactivating response RNA-binding protein (TRBP) and some other RNAi-related components [65-70]. To demonstrate the function of a gene related to the RNAi process, it is possible to silence the silencing machinery itself by injection of long dsRNA for a given target gene (a process also known as "RNAi of RNAi"), as was done for Argonaute in P. monodon [66] and for TRBP (trans-activation response RNA-binding protein) and eIF6 (eukaryotic initiation factor 6) in Marsupenaeus japonicas [69].

Argonaute (Pem-ago), a protein constituent of the RNAi machinery was studied in P. monodon by Dechklar et al. [66]. P. monodon's Argonaute, contains the signature domains PAZ and PIWI which characterize the catalytic components of the RNA-induced silencing complex. Pem-ago expression was suppressed by dsRNA administered to shrimp primary cell culture. The Pem-ago silenced cells exhibited impaired RNAi function, manifested by rescue of an endogenous gene expression from dsRNA-mediated silencing.

$M j-T R B P$ and $M j$-eIF6, both are components of RISC [69]. To investigate the role of $M j-T R B P$ and Mj-eIF6 in the RNAi pathway, shrimps were injected with dsRNA against both genes and GFP as control. The silencing of these genes was confirmed by real time RT-PCR and the shrimp were infected with WSSV. Results showed that the DNA copies of WSSV in both the TRBP-silenced group 
and the eIF6-silenced group were greatly increased compared to the group injected with GFP dsRNA, suggesting their importance in antiviral silencing of shrimp [69]

An array of genes and molecular mechanisms have been investigated within a short time frame in crustaceans, using RNAi techniques to facilitate gene-specific knockdown (Table 1). Most studies were performed in species of the commercially important order Decapoda. The ability to further accelerate the pace at which genes are being investigated in crustaceans using RNAi approach necessitates a more efficient administration method, more robust than injections, such as used in C. elegans, through feeding [22].

\section{Study of the Crustacean Innate Immune System Using RNAi}

RNAi is hypothesized to have evolved, in part, as an anti-viral mechanism [71]. Hence, harnessing RNAi to combat viruses is a reasonable choice of weaponry. Due to the immense importance of crustaceans in aquaculture and the fact that the crustacean aquaculture industry is struggling with severe viral outbreaks [72], application of RNAi for combating viruses is a field of study practiced by many research groups. In fact - half of the studies published thus far, which involve RNAi in crustaceans (see Section 3.1 and Table 3), including most of the studies which explored delivery methods of silencing agents into crustaceans (see Section 3.2 and Table 2) -investigated the option of using RNAi either to combat viruses or to study the mechanism underlying the innate immune system in crustaceans. Recent reviews on this field of research were published by Hirono et al. [73] and La Fauce and Owens [74], and prominent studies conducted in this field are summarized in Tables 2 and 3. This section will provide key examples of using RNAi to study and mitigate viral infections in crustaceans. Also summarized in this section are studies that employed alternative administration routes to dsRNA injections (Section 3.2 and Table 2), since these were performed in the context of immune system studies.

\subsection{Crustacean Innate Immune System Study through RNAi}

Dicer is an endoribonuclease which serves as a key component of the RNAi mechanism [75]. Dicer-1 silencing in the tiger shrimp P. monodon increased susceptibility to gill-associated viral infections [71], suggesting that like in other organisms RNAi is crucial for anti-viral innate immunity in crustaceans. In a study by De la Vega et al. [76], two antimicrobial peptides were silenced in the white shrimp L. vannamei, followed by challenging with pathogenic strains of bacteria, fungi and viruses. While mortality rates soared when treated shrimps were challenged with bacteria and fungi, this was not the case when challenged with white spot syndrome virus (WSSV). The researchers concluded that silencing activated the sequence-independent innate anti-viral immune response, leading to increased protection from WSSV infection. Similarly, non-specific engagement of the silencing mechanism through injection of dsRNA of various sizes ranging between $50 \mathrm{bp}$ and $200 \mathrm{bp}$, reduced mortality rates of WSSV challenged L. vannamei individuals, while siRNA (20-25 bp) injection did not reduce mortality rates [67]. 
Table 2. Summary of RNAi administration methods in crustaceans.

\begin{tabular}{|c|c|c|c|c|c|}
\hline Delivery method & Model Organinsm & Order & Year & Authors & Title \\
\hline $\begin{array}{l}\text { Injection, electroporation and transfection of DNA } \\
\text { with promoter and antisense }\end{array}$ & Litopenaeus vannamei & Decapoda & 2005 & Sun et al. & $\begin{array}{l}\text { Evaluation of methods for DNA delivery into shrimp zygotes of } \\
\text { Penaeus (Litopenaeus) vannamei }\end{array}$ \\
\hline Transfection of DNA with promoter and antisense & Litopenaeus vannamei & Decapoda & 2005 & Lu and Sun & Viral resistance in shrimp that express an antisense Taura syndrome virus coat protein gene \\
\hline Chitosan nanoparticles & Macrobrachium rosenbergii & Decapoda & 2008 & Anas et al. & $\begin{array}{l}\text { Chitosan as a wall material for a microencapsulated delivery system for } \\
\text { Macrobrachium rosenbergii (de Man) larvae }\end{array}$ \\
\hline Oral delivery of dsRNA expressing bacteria & Penaeus monodon & Decapoda & 2008 & Sarathi et al. & $\begin{array}{l}\text { Oral Administration of Bacterially Expressed VP28dsRNA to Protect Penaeus monodon } \\
\text { from White Spot Syndrome Virus }\end{array}$ \\
\hline $\begin{array}{l}\text { Oral delivery of dsRNA expressing } \\
\text { bacteria enriched Artemia }\end{array}$ & Penaeus monodon & Decapoda & 2013 & Treerattrakool et al. & $\begin{array}{l}\text { Silencing of gonad-inhibiting hormone gene expression in Penaeus monodon by feeding } \\
\text { with GIH dsRNA enriched Artemia }\end{array}$ \\
\hline
\end{tabular}

Table 3. Study of the crustacean innate immune system using RNAi.

\begin{tabular}{|c|c|c|c|c|c|c|}
\hline Field of Research & RNAi administration method & Model Organinsm & Order & Year & Authors & Title \\
\hline Anti bacterial & dsRNA injection & Pacifastacus leniusculus & Decapoda & 2007 & Liu et al. & $\begin{array}{l}\text { Phenoloxidase is an important component of the defense against Aeromonas } \\
\text { hydrophila infection in a crustacean, Pacifastacus leniusculus }\end{array}$ \\
\hline Anti bacterial & siRNA injection & Marsupenaeus japonicus & Decapoda & 2008 & Zong et al. & $\begin{array}{l}\text { Regulation of phagocytosis against bacterium by RabGTPase in shrimp } \\
\text { Marsupenaeus japonicus }\end{array}$ \\
\hline $\begin{array}{l}\text { Anti bacterial } \\
\text { and anti viral }\end{array}$ & dsRNA injection & Litopenaeus vannamei & Decapoda & 2008 & De la Vega et al. & $\begin{array}{l}\text { Anti-lipopolysaccharide factor in Litopenaeus vannamei (LvALF): A broad } \\
\text { spectrum antimicrobial peptide essential for shrimp immunity against bacterial } \\
\text { and fungal infection }\end{array}$ \\
\hline $\begin{array}{l}\text { Anti bacterial, antiviral } \\
\text { and coagulation }\end{array}$ & dsRNA injection & Marsupeneus japonicus & Decapoda & 2008 & Maningas et al. & Essential function of transglutaminase and clotting protein in shrimp immunity \\
\hline Anti bacterial & dsRNA injection & Marsupeneus japonicus & Decapoda & 2009 & Fagutao et al. & Increased bacterial load in shrimp hemolymph in the absence of prophenoloxidase \\
\hline Anti bacterial & dsRNA injection & Penaeus monodon & Decapoda & 2009 & Amparyup et al. & $\begin{array}{l}\text { Two prophenoloxidases are important for the survival of Vibrio harveyi } \\
\text { challenged shrimp Penaeus monodon }\end{array}$ \\
\hline $\begin{array}{l}\text { Anti bacterial } \\
\text { and anti fungal }\end{array}$ & dsRNA injection & Litopenaeus vannamei & Decapoda & 2009 & Shockey et al. & $\begin{array}{l}\text { The role of crustins in Litopenaeus vannamei in response to infection with shrimp } \\
\text { pathogens: An in vivo approach }\end{array}$ \\
\hline Anti viral & siRNA injection & Penaeus monodon & Decapoda & 2005 & Westenberg et al. & $\begin{array}{l}\text { siRNA injection induces sequence-independent protection in Penaeus monodon } \\
\text { against white spot syndrome virus }\end{array}$ \\
\hline
\end{tabular}


Table 3. Cont.

\begin{tabular}{|c|c|c|c|c|c|c|}
\hline Field of Research & RNAi administration method & Model Organinsm & Order & Year & Authors & Title \\
\hline Anti viral & $\begin{array}{l}\text { Injection, electroporation and } \\
\text { transfection of DNA with promoter } \\
\text { and antisense }\end{array}$ & Litopenaeus vannamei & Decapoda & 2005 & Sun et al. & $\begin{array}{l}\text { Evaluation of methods for DNA delivery into shrimp zygotes of } \\
\text { Penaeus (Litopenaeus) vannamei }\end{array}$ \\
\hline Anti viral & $\begin{array}{l}\text { Transfection of DNA with promoter } \\
\text { and antisense }\end{array}$ & Litopenaeus vannamei & Decapoda & 2005 & Lu and Sun & Viral resistance in shrimp that express an antisense Taura syndrome virus coat protein gene \\
\hline Anti viral & dsRNA injection & Penaeus monodon & Decapoda & 2006 & Assavalapsakul et al. & $\begin{array}{l}\text { Identification and characterization of a Penaeus monodon lymphoid } \\
\text { cell-expressed receptor for the yellow head virus }\end{array}$ \\
\hline Anti viral & siRNA injection & Marsupenaeus japonicus & Decapoda & 2007 & Xu et al. & Silencing shrimp white spot syndrome virus (WSSV) genes by siRNA \\
\hline Anti viral & dsRNA injection & Marsupenaeus japonicus & Decapoda & 2007 & Li et al. & $\beta$-integrin mediates WSSV infection \\
\hline Anti viral & siRNA injection & Marsupenaeus japonicus & Decapoda & 2007 & Wu et al. & $\begin{array}{l}\text { Antiviral phagocytosis is regulated by a novel Rab-dependent complex in shrimp } \\
\text { Penaeus japonicus }\end{array}$ \\
\hline Anti viral & siRNA injection & Marsupenaeus japonicus & Decapoda & 2008 & Xu et al. & $\begin{array}{l}\text { Novel function of QM protein of shrimp (Penaeus japonicus) in regulation of phenol } \\
\text { oxidase activity by interaction with hemocyanin }\end{array}$ \\
\hline Anti viral & siRNA injection & Marsupenaeus japonicus & Decapoda & 2008 & Wang et al. & Requirement for shrimp caspase in apoptosis against virus infection \\
\hline Anti viral & dsRNA injection & Penaeus monodon & Decapoda & 2008 & Ongvarrasopone et al. & Suppression of PmRab7 by dsRNA inhibits WSSV or YHV infection in shrimp \\
\hline Anti viral & dsRNA injection & Penaeus monodon & Decapoda & 2008 & Su et al. & $\begin{array}{l}\text { A key gene of the RNA interference pathway in the black tiger shrimp, Penaeus } \\
\text { monodon: Identification and functional characterisation of Dicer-1 }\end{array}$ \\
\hline Anti viral & dsRNA injection & Litopenaeus vannamei & Decapoda & 2008 & Rijiravanich et al. & $\begin{array}{l}\text { Knocking down caspase-3 by RNAi reduces mortality in Pacific white shrimp Penaeus } \\
\text { (Litopenaeus) vannamei challenged with a low dose of white-spot syndrome virus }\end{array}$ \\
\hline Anti viral & $\begin{array}{l}\text { Oral delivery of dsRNA expressing } \\
\text { bacteria }\end{array}$ & Penaeus monodon & Decapoda & 2008 & Sarathi et al. & $\begin{array}{l}\text { Oral administration of bacterially expressed VP28 dsRNA to protect } \\
\text { Penaeus monodon from White Spot Syndrome Virus }\end{array}$ \\
\hline Anti viral & siRNA and dsRNA injection & Litopenaeus vannamei & Decapoda & 2010 & Labreuche et al. & $\begin{array}{l}\text { Non-specific activation of antiviral immunity and induction of RNA interference may } \\
\text { engage the same pathway in the Pacific white leg shrimp Litopenaeus vannamei }\end{array}$ \\
\hline Anti viral & dsRNA injection & Penaeus monodon & Decapoda & 2011 & $\begin{array}{l}\text { Woramongkolchai } \\
\text { et al. }\end{array}$ & $\begin{array}{l}\text { The possible role of penaeidin } 5 \text { from the black tiger shrimp, Penaeus monodon, in } \\
\text { protection against viral infection }\end{array}$ \\
\hline Anti viral & \multicolumn{3}{|c|}{ Review on the study of innate immune system in crustaceans using RNAi } & 2011 & Hirono et al. & Uncovering the mechanisms of shrimp innate immune response by RNA interference \\
\hline Anti viral & \multicolumn{3}{|c|}{ Review on RNAi in crustaceans with emphasis of antiviral capabilities } & 2012 & La Fauce and Owens & RNA interference with special reference to combating viruses of crustacea \\
\hline Anti viral & dsRNA injection Litopenaeus vannan & ei Decapoda & & 2013 & Lin et al. & $\begin{array}{l}\text { Characterization of white shrimp Litopenaeus vannamei integrin } \mathrm{b} \text { and its role in } \\
\text { immunomodulation by dsRNA-mediated gene silencing }\end{array}$ \\
\hline
\end{tabular}


In another study in L. vannamei, silencing crustin, an anti-microbial peptide suspected to also inhibit fungal growth - was followed by injection of pathogenic bacteria or fungi. While mortality rates rose in crustin-depleted individuals challenged with bacteria, no change was observed in crustin-depleted individuals challenged with fungi [77]. The sequence-independent immune response was not tested in this study. In yet another study, the transcript level of penaeidin5, an antimicrobial peptide of the marine shrimp $F$. chinensis, was elevated $24 \mathrm{~h}$ after WSSV challenging, followed by a sharp decline after $48 \mathrm{~h}$. Since transcript levels were correlated with viral titer, the researchers sought to investigate the anti-viral function of penaeidin5. Silencing penaeidin5 increased the transcript level of VP28, a coat protein of WSSV [78]. This study provided the first evidence for a penaeidin that is anti-viral. The clotting mechanism, the first line of defense in crustaceans [79], was also implicated in anti-viral defense. Silencing of two components of the clotting mechanism followed by challenging the treated shrimp with bacteria and viruses, both resulted in higher mortality rates in the silenced individuals [80].

Caspase-3 is a cysteine protease which is the effector in apoptosis, necrosis and inflammation [81]. Silencing of caspase-3 in the marine shrimp Marsupenaeus japonicus through siRNA injections inhibited WSSV-induced apoptosis and led to an increase in observed viral copy numbers, suggesting that apoptosis is an anti-viral mechanism in this species [82]. This notion was strengthened by silencing of caspase-3 in the white shrimp L. vannamei (through dsRNA injections) which resulted in increased mortality following challenging with WSSV [83]. These results are contradictory to the same intervention in mammalian cell lines, where caspase-3 knock-down by siRNA impaired influenza propagation [84]. This contradiction emphasizes the differences in anti-viral defense mechanisms between arthropods and vertebrates.

Anti-bacterial as well as anti-viral phagocytosis, which precedes caspase-3 activity, was studied in the marine shrimp M. japonicus. Silencing a Rab GTPase - a major component of endocytosis as well as phagocytosis - decreased phagocytosis activity in vibrio sp. challenged individuals [85] and increased the copy number of WSSV with which treated shrimp were challenged [86], suggesting that a Rab-dependent complex plays a role in anti-bacterial as well as anti-viral phagocytic activity in crustaceans. Ongvarrasopone et al. [87] found that silencing Rab GTPase in P. monodon reduces proliferation of both WSSV- and yellow head virus (YHV) in challenged individuals, suggesting that tackling the phagocytosis process might be beneficial against an array of viruses. Through incubating YHV with membrane extracts of $P$. monodon lymphoid organ, a $65 \mathrm{kDa}$ receptor was identified. Silencing of the receptor followed by challenging with YHV completely inhibited the entry of the virus, suggesting that this is the receptor employed by the virus to enter the host cells [88].

Prophenol oxidase (proPO) is the terminal enzyme in the melanization cascade, an important innate immune system in crustaceans [89]. ProPO silencing in the shrimp M. japonicus induced mortality due to bacterial build up, which was counteracted by antibiotic treatment. A microarray revealed that expression levels of several antimicrobial peptides were reduced in proPO silenced individuals [90]. Two proPO genes were identified in the closely related tiger shrimp P. monodon. Silencing of each of the two, followed by challenging with the pathogenic bacterium Vibrio harveyi increased mortality, suggesting that both genes are active components of the melanization process in P. monodon [91]. Silencing of proPO in the crayfish Pacifastacus leniusculus followed by challenging with a pathogenic bacterium increased mortality, while silencing of pacifastin, an inhibitor of the crayfish proPO 
activation cascade, delayed mortality [92]. Silencing of the QM protein, a tumor suppressor candidate showed that it regulates proPO levels in the shrimp M. japonicas [93].

Through co-immunoprecipitation, $\beta$-integrin was found to interact with a WSSV coat protein in $M$. japonicus. Silencing $\beta$-integrin reduced mortality in WSSV-challenged individuals [94], suggesting $\beta$-integrin is yet another key for viral invasion into host cells. An array of immuno related genes, exhibited varying expression levels following $\beta$-integrin silencing in $L$. vannamei. $\beta$-integrin involvement was suggested in: proPO activation, phagocytosis, and the antioxidant system for immunomodulation in shrimp [84].

In summary, within a short period of time, RNAi has become a key method to explore an array of cellular processes involved in anti-viral defense mechanisms in non-model crustaceans of commercial importance. This exemplifies the RNAi ease-of-use and the vast interest in this method for paving new application avenues in this field of research.

\subsection{Anti Viral-Related Administration Methods}

Administration methods in crustaceans have mainly been explored in the context of viral defense. Attempts were made to vaccinate crustaceans by administering DNA constructs, which express viral capsid genes [95,96], as well as silencing compounds (namely dsRNA, siRNA and shRNA). Sun et al. [8] explored an array of methods for transfecting white shrimp (L. vannamei) zygotes with DNA constructs of a taura syndrome virus (TSV) coat protein anti-sense, transcribed under the control of beta-actin promoter. The methods included microinjection, electroporation and transfecting with a commercially available transfecting reagent. The transfecting reagent proved to be the most efficient method as it is up-scalable and simple and yields high hatching rate, gene transfer efficiency, and survival rate [7]. The major drawback of this method is that unlike temporal silencing compounds (dsRNA/siRNA/shRNA), DNA transfection might produce a genetically modified organism (GMO).

Sarathi et al. [97] explored oral administration methods including dsRNA-producing bacteria and dsRNA-chitosan nanoparticles. The dsRNA targeted the coat protein of the WSSV and the bioassay included mortality rates following oral challenging with WSSV. Mortality rates were reduced by $37 \%$ and $68 \%$ in the dsRNA-producing bacteria and dsRNA-chitosan nanoparticles-fed individuals, respectively. Anas et al. [98] further characterized the properties of chitosan nanoparticles and concluded that they are suitable for encapsulating drugs for oral delivery into $M$. rosenbergii larvae. While this approach proved useful to some extent, only one very recent report has examined the option of using oral delivery to silence a gene systemically in crustaceans (summarized in Section 3.3). This method might only be useful for protecting against water-borne viruses, rather than for silencing of endogenous genes. Contradictory to the findings by Sarathi et al. [97], when P. monodon individuals were challenged with a lethal dose of a gill associated virus, mortality was not reduced when fed with dsRNA-producing bacteria, while intramuscular dsRNA injections did lead to a decrease in mortality [99].

Using the same WSSV coat protein as the silencing target, $\mathrm{Xu}$ et al. [100] showed that a 21 nucleotide-long siRNA is capable of eradicating WSSV from infected Penaeus japonicus shrimp following three injections. These researchers showed that a single mutation eliminates the siRNA activity. Contrary to the above, Westenberg et al. [101] found that in P. monodon siRNA acts in a 
non-specific manner, reducing mortality of WSSV-challenged shrimp individuals, regardless of whether the siRNA is designed to silence expression of WSSV coat proteins.

In summary, the predominance of viral-related studies that employ RNAi in crustaceans reflects the need of the aquaculture industry to mitigate the ever-increasing threat of viral-induced collapses of cultured crustacean ponds. The study of administration methods in this context might pave the way towards a more robust use of RNAi in various fields of study in crustaceans.

\subsection{Oral Administered Silencing of a Systemic Gene}

In a recent study, an attempt was made to silence an endogenous gene in crustaceans through oral delivery [50]. In this study previously successful silencing through dsRNA injections of GIH in P. monodon [48] was repeated, this time by feeding with Artemia salina enriched with dsRNA expressing bacteria. Although a significant decrease in $G I H$ transcript levels was observed, it was much less pronounced than with the dsRNA injections. This study indicates that it is feasible to induce silencing in crustaceans through orally-administered silencing compounds although further study is required to increase the efficiency. One plausible route would be the use of siRNA instead of dsRNA.

\section{The First Case of a Biotechnological Use of Gene Silencing in the Aquaculture Industry (Crustacean Monosex Culture)}

The opportunities opened by gene silencing in crustaceans are immense and indeed the first commercialized RNAi based biotechnology implemented in the aquaculture industry was achieved in a prawn (decapod crustacean) culture as described below.

\subsection{Sexual Dimorphism and Monosex Culture of Prawns}

Gender, sexual maturity and reproductive activity are among the factors affecting growth rates of crustaceans under aquaculture conditions [102-104]. This is most notable in crustacean species which exhibit bimodal growth patterns in which males grow faster than females or vice versa [102], among these are the most popular decapod cultured groups (shrimp, prawns, crayfish and crabs). The bimodal growth phenomenon has led to the assumption that culturing each gender separately, as commonly done in agriculture in the major cases of animal husbandry (e.g., cattle and poultry) might be of advantage for crustacean cultures as well. This assumption is based on the understanding that differences between males and females in terms of growth rate, alimentary needs and behavioral patterns dictate the need to establish management systems specifically tailored to one sex or the other. Moreover, non-breeding monosex populations may divert energy from reproduction to growth. Based on these assumptions, attempts have been made to apply the monosex husbandry into crustacean aquaculture $[105,106]$.

The giant freshwater prawn, M. rosenbergii (de Man), which is a popular aquaculture species, displays clear dimorphic growth in which males reach significantly larger sizes than females [107]. Thus, a preliminary attempt to grow the prawns under gender separation was made in a small-scale cage-culture system, clearly demonstrating the advantage of all-male yields compared to a mixed population [108]. In addition to the higher yields, the all-male culture of $M$. rosenbergii proved later to 
be economically beneficial with a $60 \%$ income increase under Indian conditions [109]. The unmet need thus was a viable biotechnology for producing monosex prawn populations, and this was established by manipulating the endocrinic control of sexual differentiation in crustaceans in the androgenic gland [110].

\subsection{The Androgenic Gland and Its Secretion}

The androgenic gland (AG) was suggested by Charniaux-Cotton [111] to mediate sexual differentiation in crustaceans and nowadays it is accepted that the gland plays a central role in this function [112-114]. Touir [115] described the effects of the AG on both primary and secondary male characteristics in a number of decapod crustaceans, and Taketomi et al. [116] showed the same using AG extracts in the crayfish Procambarus clarkii. More recently, it was shown that AG implantation into females of the crayfish C. quadricarinatus and the mud crab Scylla paramamosain inhibited vitellogenesis, resulted in ovarian regression with degeneration oocytes and promoted growth $[117,118]$.

The ultrastructure of a decapod crustacean AG cell resembles that of a vertebrate protein-producing cell rather than that of a steroid-producing cell, thus it appears that unlike in vertebrates, it is proteins rather than steroids that are responsible for the control of sexual differentiation [119]. Histological evidence [120] and changes in total protein content in specific AG cell types [121] in M. rosenbergii support this notion. This is further supported by purification, identification and full DNA sequencing of the AG hormone in isopods [122,123]. Similarly, in recent years, insulin-like AG hormone encoding transcripts were discovered and fully sequenced in all economically important groups of decapod crustaceans including shrimp, crabs, prawns and crayfish [63,64,124-126].

\subsection{RNAi Based Biotechnology for All-Male Culture}

Following the discovery of the insulin-like AG hormone encoding transcript in the prawn M. rosenbergii (Mr-IAG), gene silencing through RNAi was used to knock down this crustacean sexual differentiation-related gene [63]. When performed at an early developmental stage of juvenile males, identified through the use of molecular sex markers [127], Mr-IAG silencing induced a full and functional sex reversal of males into neo-females. Successfully mated with untreated males, the neo-females produced all-male progeny [16]. This marked the first commercialization of the process and establishment of a technology that does not involve the use of chemicals/hormones and does not involve genetic modification of the target organism. Since the intervention is temporal and performed on parent prawns, it is not transmissible to next generations and thus free of the regulatory hurdles required from genetically-modified crops [128]. Based on these advantages and with further developments of delivery methodologies, in the coming years we will probably see gene silencing applications emerging in many aspects of crustacean culture and aquaculture in general.

\section{Conclusions}

Within the short period of time since its discovery, RNAi has served to enhance basic scientific knowledge through the discovery of the function of a wide array of genes and molecular mechanisms in crustaceans. RNAi has also become a key method to explore cellular processes involved in anti-viral 
defense mechanisms in non-model crustaceans of commercial importance. Indeed, the first commercialized RNAi-based biotechnology in the aquaculture industry was achieved in prawns (decapod crustacean).

To further accelerate the pace at which RNAi can be used in the investigation of genes, in various fields of study in crustaceans, a more efficient administration method tailored to these organisms is required.

This review exemplifies the ease-of-use of RNAi, the vast interest in this method and the immense opportunities opened by gene silencing in the field of crustacean research and development.

\section{Acknowledgments}

This study was supported in part by grants from The United States-Israel Binational Agricultural Research and Development Fund (BARD, Grant No. IS-4493-12), the National Institute for Biotechnology in the Negev (NIBN) and a Discovery Early Career Research Award to TV (DECRA, Grant No. DE130101089) granted by the Australian Research Council.

\section{Conflicts of Interest}

The authors declare no conflict of interest.

\section{References}

1. Fire, A.; Xu, S.; Montgomery, M.K.; Kostas, S.A.; Driver, S.E.; Mello, C.C. Potent and specific genetic interference by double-stranded RNA in Caenorhabditis elegans. Nature 1998, 391, 806-811.

2. Dorsett, Y.; Tuschl, T. siRNAs: Applications in functional genomics and potential as therapeutics. Nat. Rev. Drug Discov. 2004, 3, 318-329.

3. Fire, A.Z.; Mello, C.C. The Nobel Prize in Physiology or Medicine 2006. Available online: http://www.nobelprize.org/nobel_prizes/medicine/laureates/2006/ (accessed on 26 January 2013).

4. Agrawal, N.; Dasaradhi, P.V.N.; Mohmmed, A.; Malhotra, P.; Bhatnagar, R.K.; Mukherjee, S.K. RNA interference: Biology, mechanism, and applications. Microbiol. Mol. Biol. Rev. 2003, 67, 657-685.

5. Qi, Y.J.; Hannon, G.J. Uncovering RNAi mechanisms in plants: Biochemistry enters the foray. FEBS Lett. 2005, 579, 5899-5903.

6. Watson, J.M.; Fusaro, A.F.; Wang, M.B.; Waterhouse, P.M. RNA silencing platforms in plants. FEBS Lett. 2005, 579, 5982-5987.

7. Lu, Y.; Sun, P.S. Viral resistance in shrimp that express an antisense Taura syndrome virus coat protein gene. Antivir. Res. 2005, 67, 141-146.

8. Sun, P.S.; Venzon, N.C., Jr.; Calderon, F.R.O.; Esaki, D.M. Evaluation of methods for DNA delivery into shrimp zygotes of Penaeus (Litopenaeus) vannamei. Aquaculture 2005, 243, 19-26.

9. Söderhäll, I.; Kim, Y.-A.; Jiravanichpaisal, P.; Lee, S.-Y.; Söderhäll, K. An ancient role for a Prokineticin domain in invertebrate hematopoiesis. J. Immunol. 2005, 174, 6153-6160. 
10. Robalino, J.; Browdy, C.L.; Prior, S.; Metz, A.; Parnell, P.; Gross, P.; Warr, G. Induction of antiviral immunity by double-stranded RNA in a marine invertebrate. J. Virol. 2004, 78, 10442-10448.

11. Robalino, J.; Bartlett, T.; Shepard, E.; Prior, S.; Jaramillo, G.; Scura, E.; Chapman, R.W.; Gross, P.S.; Browdy, C.L.; Warr, G.W. Double-stranded RNA induces sequence-specific antiviral silencing in addition to nonspecific immunity in a marine shrimp: Convergence of RNA interference and innate immunity in the invertebrate antiviral response? J. Virol. 2005, 79, 13561-13571.

12. Kim, S.-S.; Garg, H.; Joshi, A.; Manjunath, N. Strategies for targeted nonviral delivery of siRNAs in vivo. Trends Mol. Med. 2009, 15, 491-500.

13. Ahyong, S.T.; Lowry, J.K.; Alonso, M.; Bamber, R.N.; Boxshall, G.A.; Castro, P.; Gerken, S.; Karaman, G.S.; Goy, J.W.; Jones, D.S.; et al. Subphylum Crustacea Brünnich, 1772. In Animal Biodiversity: An Outline of Higher-Level Classification and Survey of Taxonomic Richness; Zhang, Z.Q., Ed.; Magnolia Press: Auckland, New Zealand, 2011; pp. 165-191.

14. LeBlanc, G.A. Crustacean endocrine toxicology: A review. Ecotoxicology 2007, 16, 61-81.

15. Stillman, J.H. Acclimation capacity underlies susceptibility to climate change. Science 2003, 301,65 .

16. Ventura, T.; Sagi, A. The insulin-like androgenic gland hormone in crustaceans: From a single gene silencing to a wide array of sexual manipulation-based biotechnologies. Biotechnol. Adv. 2012, 30, 1543-1550.

17. Gherardi, F.; Aquiloni, L.; Diéguez-Uribeondo, J.; Tricarico, E. Managing invasive crayfish: Is there a hope? Aquat. Sci. 2011, 73, 185-200.

18. Glenner, H.; Thomsen, P.F.; Hebsgaard, M.B.; Sørensen, M.V.; Willerslev, E. The origin of insects. Science 2006, 314, 1883-1884.

19. Lukhtanov, V.; Kuznetsova, V. What genes and chromosomes say about the origin and evolution of insects and other arthropods. Russ. J. Genet. 2010, 46, 1115-1121.

20. Sorgeloos, P.; Dhert, P.; Candreva, P. Use of the brine shrimp, Artemia spp., in marine fish larviculture. Aquaculture 2001, 200, 147-159.

21. Colbourne, J.K.; Pfrender, M.E.; Gilbert, D.; Thomas, W.K.; Tucker, A.; Oakley, T.H.; Tokishita, S.; Aerts, A.; Arnold, G.J.; Basu, M.K.; et al. The ecoresponsive genome of Daphnia pulex. Science 2011, 331, 555-561.

22. Kamath, R.S.; Ahringer, J. Genome-Wide RNAi screening in Caenorhabditis elegans. Methods 2003, 30, 313-321.

23. Aigner, A. Delivery systems for the direct application of siRNAs to induce RNA interference (RNAi) in vivo. J. Biomed. Biotechnol. 2006, 2006, ArticleID 71659.

24. Luquet, G.; Marin, F. Biomineralisations in crustaceans: Storage strategies. C. R. Palevol. 2004, 3, 515-534.

25. Travis, D.F. The deposition of skeletal structures in the Crustacea. 1. The histology of the gastrolith skeletal tissue complex and the gastrolith in the crayfish, Orconectes (cambaus) verilis Hagen-Decapoda. Biol. Bull. 1960, 16, 137-149.

26. Travis, D.F.; Friberg, U. The deposition of skeletal structures in the crustacea. Vi. Microradiographic studies of the exoskeleton of the crayfish Orconectes virilis hagen. J. Ultrastruct. Res. 1963, 59, 285-301. 
27. Shechter, A.; Glazer, L.; Cheled, S.; Mor, E.; Weil, S.; Berman, A.; Bentov, S.; Aflalo, E.D.; Khalaila, I.; Sagi, A. A gastrolith protein serving a dual role in the formation of an amorphous mineral containing extracellular matrix. Proc. Natl. Acad. Sci. USA 2008, 105, 7129-7134.

28. Glazer, L.; Shechter, A.; Tom, M.; Yudkovski, Y.; Weil, S.; Aflalo, E.D.; Pamuru, R.R.; Khalaila, I.; Bentov, S.; Berman, A.; et al. A protein involved in the assembly of an extracellular calcium storage matrix. J. Biol. Chem. 2010, 258, 12831-12839.

29. Hughes, C.L.; Kaufman, T.C. Hox genes and the evolution of the arthropod body plan. Evol. Dev. 2002, 4, 459-499.

30. Copf, T.; Rabet, N.; Averof, M. Knockdown of spalt function by RNAi causes de-repression of Hox genes and homeotic transformations in the crustacean Artemia franciscana. Dev. Biol. 2006, 298, 87-94.

31. Liubicich, D.M.; Serano, J.M.; Pavlopoulos, A.; Kontarakis, Z.; Protas, M.E.; Kwan, E.; Chatterjee, S.; Tran, K.D.; Averof, M.; Patel, N.H.; et al. Knockdown of Parhyale Ultrabithorax recapitulates evolutionary changes in crustacean appendage morphology. Proc. Natl. Acad. Sci. USA 2009, 106, 13892-13896.

32. Kato, Y.; Shiga, Y.; Kobayashi, K.; Tokishita, S.-I.; Yamagata, H.; Iguchi, T.; Watanabe, H. Development of an RNA interference method in the cladoceran crustacean Daphnia magna. Dev. Genes Evol. 2011, 220, 337-345.

33. Ventura, T.; Manor, R.; Aflalo, E.D.; Chalifa-Caspi, V.; Weil, S.; Sharabi, O.; Sagi, A. Post-Embryonic transcriptomes of the prawn Macrobrachium rosenbergii: Multigenic succession through metamorphosis. PLoS One 2013, 8, e55322.

34. Laufer, H.; Borst, D.; Baker, F.C.; Reuter, C.C.; Tsai, L.W.; Schooley, D.A.; Carrasco, C.; Sinkus, M. Identification of a juvenile hormone-like compound in a crustacean. Science 1987, 235, 202-205.

35. Hui, J.H.L.; Tobe, S.S.; Chan, S.-M. Characterization of the putative farnesoic acid $O$-methyltransferase (LvFAMeT) cDNA from white shrimp, Litopenaeus vannamei: Evidence for its role in molting. Peptides 2008, 29, 252-260.

36. Sonanez-Organis, J.G.; Peregrino-Uriarte, A.B.; Gomez-Jimenez, S.; Lopez-Zavala, A.; Forman, H.J.; Yepiz-Plascencia, G. Molecular characterization of hypoxia inducible factor-1 (HIF-1) from the white shrimp Litopenaeus vannamei and tissue-specific expression under hypoxia. Comp. Biochem. Phys. C 2009, 150, 395-405.

37. Soñanez-Organis, J.G.; Racotta, I.S.; Yepiz-Plascencia, G. Silencing of the hypoxia inducible factor 1 -HIF-1- obliterates the effects of hypoxia on glucose and lactate concentrations in a tissue-specific manner in the shrimp Litopenaeus vannamei. J. Exp. Mar. Biol. Ecol. 2010, 393, 51-58.

38. De Santis, C.; Wade, N.M.; Jerry, D.R.; Preston, N.P.; Glencross, B.D.; Sellars, M.J. Growing backwards: An inverted role for the shrimp ortholog of vertebrate myostatin and GDF11. J. Exp. Biol. 2011, 214, 2671-2677.

39. Hermann, A.; Cox, J.A. Sarcoplasmic calcium-binding protein. Comp. Biochem. Physiol. B Biochem. Mol. Biol. 1995, 111, 337-345. 
40. White, A.J.; Northcutt, M.J.; Rohrback, S.E.; Carpenter, R.O.; Niehaus-Sauter, M.M.; Gao, Y.P.; Wheatly, M.G.; Gillen, C.M. Characterization of sarcoplasmic calcium binding protein (SCP) variants from freshwater crayfish Procambarus clarkii. Comp. Biochem. Physiol. B Biochem. Mol. Biol. 2011, 160, 8-14.

41. Keller, R. Crustacean neuropeptides: Structures, functions and comparative aspects. Experientia 1992, 48, 439-448.

42. Webster, S.G. Measurement of crustacean hyperglycaemic hormone levels in the edible crab Cancer pagurus during emersion stress. J. Exp. Biol. 1996, 199, 1579-1585.

43. Lugo, J.M.; Morera, Y.; Rodríguez, T.; Huberman, A.; Ramos, L.; Estrada, M.P. Molecular cloning and characterization of the crustacean hyperglycemic hormone cDNA from Litopenaeus schmitti. FEBS J. 2006, 273, 5669-5677.

44. Tiu, S.H.-K.; Chan, S.-M. The use of recombinant protein and RNA interference approaches to study the reproductive functions of a gonad-stimulating hormone from the shrimp Metapenaeus ensis. FEBS J. 2007, 274, 4385-4395.

45. Webster, S.G.; Keller, R.; Dircksen, H. The CHH-superfamily of multifunctional peptide hormones controlling crustacean metabolism, osmoregulation, moulting, and reproduction. Gen. Comp. Endocrinol. 2012, 175, 217-233.

46. Pamuru, R.R.; Rosen, O.; Manor, R.; Chung, J.S.; Zmora, N.; Glazer, L.; Aflalo, E.D.; Weil, S.; Tamone, S.L.; Sagi, A. Stimulation of molt by RNA interference of the molt-inhibiting hormone in the crayfish Cherax quadricarinatus. Gen. Comp. Endocrinol. 2012, 178, 227-236.

47. Tiu, S.H.K.; He, J.-G.; Chan, S.-M. The LvCHH-ITP gene of the shrimp (Litopenaeus vannamei) produces a widely expressed putative ion transport peptide (LvITP) for osmo-regulation. Gene 2007, 396, 226-235.

48. Treerattrakool, S.; Panyim, S.; Chan, S.-M.; Withyachumnarnkul, B.; Udomkit, A. Molecular characterization of gonad-inhibiting hormone of Penaeus monodon and elucidation of its inhibitory role in vitellogenin expression by RNA interference. FEBS J. 2008, 275, 970-980.

49. Treerattrakool, S.; Panyim, S.; Udomkit, A. Induction of ovarian maturation and spawning in Penaeus monodon broodstock by double-stranded RNA. Mar. Biotechnol. 2011, 13, 163-169.

50. Treerattrakool, S.; Chartthai, C.; Phromma-in, N.; Panyim, S.; Udomkit, A. Silencing of gonad-inhibiting hormone gene expression in Penaeus monodon by feeding with GIH dsRNA enriched Artemia. Aquaculture 2013, 404, 116-121.

51. Sathapondecha, P.; Treerattrakool, S.; Panyim, S.; Udomkit, A. Potential roles of transglutaminase and thioredoxin in the release of gonad-stimulating factor in Penaeus monodon: Implication from differential expression in the brain during ovarian maturation cycle. Mar. Genom. 2011, 4, 279-285.

52. Sharabi, O.; Ventura, T.; Manor, R.; Aflalo, E.D.; Sagi, A. Epidermal growth factor receptor in the prawn Macrobrachium rosenbergii: Function and putative signaling cascade. Endocrinology 2013, 154, 3188-3196.

53. Tiu, S.H.K.; Benzie, J.; Chan, S.-M. From hepatopancreas to ovary: Molecular characterization of a shrimp vitellogenin receptor involved in the processing of vitellogenin. Biol. Reprod. 2008, 79, 66-74. 
54. Das, S.; Durica, D.S. Ecdysteroid receptor signaling disruption obstructs blastemal cell proliferation during limb regeneration in the fiddler crab, Uca pugilator. Mol. Cell. Endocrinol. 2013, 365, 249-259.

55. Priya, T.A.J.; Li, F.; Zhang, J.; Wang, B.; Zhao, C.; Xiang, J. Molecular characterization and effect of RNA interference of retinoid X receptor (RXR) on E75 and chitinase gene expression in Chinese shrimp Fenneropenaeus chinensis. Comp. Biochem. Physiol. Part. B Biochem. Mol. Biol. 2009, 153, 121-129.

56. Freeman, M. Reiterative use of the EGF receptor triggers differentiation of all cell types in the Drosophila eye. Cell 1996, 87, 651-660.

57. Kono, M.; Wilder, M.N.; Matsui, T.; Furukawa, K.; Koga, D.; Aida, K. Chitinolytic enzyme activities in the hepatopancreas, tail fan and hemolymph of kuruma prawn Penaeus Japonicus during the molt cycle. Fish. Sci. 1995, 61, 727-728.

58. Priya, T.A.J.; Li, F.; Zhang, J.; Yang, C.; Xiang, J. Molecular characterization of an ecdysone inducible gene E75 of Chinese shrimp Fenneropenaeus chinensis and elucidation of its role in molting by RNA interference. Comp. Biochem. Physiol. Part. B Biochem. Mol. Biol. 2010, 156, 149-157.

59. Nagaraju, G.P.C.; Rajitha, B.; Borst, D.W. Molecular cloning and sequence of retinoid X receptor in the green crab Carcinus maenas: A possible role in female reproduction. J. Endocrinol. 2011, 210, 379-390.

60. Kato, Y.; Kobayashi, K.; Watanabe, H.; Iguchi, T. Environmental sex determination in the branchiopod crustacean Daphnia magna: Deep conservation of a Doublesex gene in the sex-determining pathway. PLoS Genet. 2011, 7, e1001345.

61. Charniaux-Cotton, H. Androgenic gland of crustaceans. Gen. Comp. Endocrinol. 1962, 1, 241-247.

62. Rosen, O.; Manor, R.; Weil, S.; Gafni, O.; Linial, A.; Aflalo, E.D.; Ventura, T.; Sagi, A. A sexual shift induced by silencing of a single insulin-like gene in crayfish: Ovarian upregulation and testicular degeneration. PLoS One 2010, 5, e15281.

63. Ventura, T.; Manor, R.; Aflalo, E.D.; Weil, S.; Raviv, S.; Glazer, L.; Sagi, A. Temporal silencing of an androgenic gland-specific insulin-like gene affecting phenotypical gender differences and spermatogenesis. Endocrinology 2009, 150, 1278-1286.

64. Ventura, T.; Manor, R.; Aflalo, E.D.; Weil, S.; Rosen, O.; Sagi, A. Timing sexual differentiation: Full functional sex reversal achieved through silencing of a single insulin-like gene in the prawn, Macrobrachium rosenbergii. Biol. Reprod. 2012, 86, 90-96.

65. Chen, Y.H.; Jia, X.T.; Zhao, L.; Li, C.Z.; Zhang, S.A.; Chen, Y.G.; Weng, S.P.; He, J.G. Identification and functional characterization of Dicer2 and five single VWC domain proteins of Litopenaeus vannamei. Dev. Comp. Immunol. 2011, 35, 661-671.

66. Dechklar, M.; Udomkit, A.; Panyim, S. Characterization of Argonaute cDNA from Penaeus monodon and implication of its role in RNA interference. Biochem. Biophys. Res. Commun. 2008, 367, 768-774.

67. Labreuche, Y.; Veloso, A.; de la Vega, E.; Gross, P.S.; Chapman, R.W.; Browdy, C.L.; Warr, G.W. Non-Specific activation of antiviral immunity and induction of RNA interference may engage the same pathway in the Pacific white leg shrimp Litopenaeus vannamei. Dev. Comp. Immunol. 2010, 34, 1209-1218. 
68. Su, J.S.; Oanh, D.T.H.; Lyons, R.E.; Leeton, L.; van Hulten, M.C.W.; Tan, S.H.; Song, L.; Rajendran, K.V.; Walker, P.J. A key gene of the RNA interference pathway in the black tiger shrimp, Penaeus monodon: Identification and functional characterisation of Dicer-1. Fish. Shellfish Immunol. 2008, 24, 223-233.

69. Wang, S.; Chen, A.J.; Shi, L.J.; Zhao, X.F.; Wang, J.X. TRBP and eIF6 homologue in Marsupenaeus japonicus play crucial roles in antiviral response. PLoS One 2012, 7, e30057.

70. Yao, X.M.; Wang, L.L.; Song, L.S.; Zhang, H.A.; Dong, C.H.; Zhang, Y.; Qiu, L.M.; Shi, Y.H.; Jianmin, Z.M.; Bi, Y.K. A Dicer-1 gene from white shrimp Litopenaeus vannamei: Expression pattern in the processes of immune response and larval development. Fish. Shellfish Immunol. 2010, 29, 565-570.

71. Shabalina S.A.; Koonin E.V. Origins and evolution of eukaryotic RNA interference. Trends Ecol. Evol. 2008, 23, 578-587.

72. Stentiford, G.D.; Bonami, J.R.; Alday-Sanz, V. A critical review of susceptibility of crustaceans to Taura syndrome, Yellowhead disease and White Spot Disease and implications of inclusion of these diseases in European legislation. Aquaculture 2009, 291, 1-17.

73. Hirono, I.; Fagutao, F.F.; Kondo, H.; Aoki, T. Uncovering the mechanisms of shrimp innate immune response by RNA interference. Mar. Biotechnol. 2011, 13, 622-628.

74. La Fauce, K.; Owens, L. RNA interference with special reference to combating viruses of crustacea. Indian J. Virol. 2012, 23, 226-243.

75. Heinrichs, A. RISC assessment. Nat. Rev. Mol. Cell. Biol. 2004, 5, 334.

76. De la Vega, E.; O’Leary, N.A.; Shockey, J.E.; Robalino, J.; Payne, C.; Browdy, C.L.; Warr, G.W.; Gross, P.S. Anti-Lipopolysaccharide factor in Litopenaeus vannamei (LvALF): A broad spectrum antimicrobial peptide essential for shrimp immunity against bacterial and fungal infection. Mol. Immunol. 2008, 45, 1916-1925.

77. Shockey, J.E.; O'Leary, N.A.; de la Vega, E.; Browdy, C.L.; Baatz, J.E.; Gross, P.S. The role of crustins in Litopenaeus vannamei in response to infection with shrimp pathogens: An in vivo approach. Dev. Comp. Immunol. 2009, 33, 668-673.

78. Woramongkolchai, N.; Supungul, P.; Tassanakajon, A. The possible role of penaeidin5 from the black tiger shrimp, Penaeus monodon, in protection against viral infection. Dev. Comp. Immunol. 2011, 35, 530-536.

79. Vazquez, L.; Alpuche, J.; Maldonado, G.; Agundis, C.; Pereyra-Morales, A.; Zenteno, E. Review: Immunity mechanisms in crustaceans. Innate Immun. 2009, 15, 179-188.

80. Maningas, M.B.B.; Kondo, H.; Hirono, I.; Saito-Taki, T.; Aoki, T. Essential function of transglutaminase and clotting protein in shrimp immunity. Mol. Immunol. 2008, 45, 1269-1275.

81. Portera, A.G.; Jänicke, R.U. Emerging roles of caspase-3 in apoptosis. Cell. Death Differ. 1999, 6, 99-104.

82. Wang, L.; Zhi, B.; Wu, W.; Zhang, X. Requirement for shrimp caspase in apoptosis against virus infection. Dev. Comp. Immunol. 2008, 32, 706-715.

83. Rijiravanich, A.; Browdy, C.L.; Withyachumnarnkul, B. Knocking down caspase-3 by RNAi reduces mortality in Pacific white shrimp Penaeus (Litopenaeus) vannamei challenged with a low dose of white-spot syndrome virus. Fish. Shellfish Immunol. 2008, 24, 308-313. 
84. Lin, Y.-C.; Chen, J.-C.; Chen, Y.-Y.; Liu, C.-H.; Cheng, W.; Hsu, C.-H.; Tsui, W.-C. Characterization of white shrimp Litopenaeus vannamei integrin $\beta$ and its role in immunomodulation by dsRNA-mediated gene silencing. Dev. Comp. Immunol. 2013, 40, 167-179.

85. Zong, R.; Wu, W.; Xu, J.; Zhang, X. Regulation of phagocytosis against bacterium by Rab GTPase in shrimp Marsupenaeus japonicus. Fish. Shellfish Immunol. 2008, 25, 258-263.

86. Wu, W.; Zong, R.; Xu, J.; Zhang, X. Antiviral phagocytosis is regulated by a novel Rab-dependent complex in shrimp Penaeus japonicus. J. Proteome Res. 2007, 7, 424-431.

87. Ongvarrasopone, C.; Chanasakulniyom, M.; Sritunyalucksana, K.; Panyim, S. Suppression of PmRab7 by dsRNA inhibits WSSV or YHV infection in shrimp. Mar. Biotechnol. 2008, 10, 374-381.

88. Assavalapsakul, W.; Smith, D.R.; Panyim, S. Identification and characterization of a Penaeus monodon lymphoid cell-expressed receptor for the yellow head virus. J. Virol. 2006, 80, 262-269.

89. Johansson, M.W.; Soderhall, K. Cellular immunity in crustaceans and the proPO system. Parasitol. Today 1989, 5, 171-176.

90. Fagutao, F.F.; Koyama, T.; Kaizu, A.; Saito-Taki, T.; Kondo, H.; Aoki, T.; Hirono, I. Increased bacterial load in shrimp hemolymph in the absence of prophenoloxidase. FEBS J. 2009, 276, 5298-5306.

91. Amparyup, P.; Charoensapsri, W.; Tassanakajon, A. Two prophenoloxidases are important for the survival of Vibrio harveyi challenged shrimp Penaeus monodon. Dev. Comp. Immunol. 2009, 33, 247-256.

92. Liu, H.; Jiravanichpaisal, P.; Cerenius, L.; Lee, B.L.; Söderhäll, I.; Söderhäll, K. Phenoloxidase is an important component of the defense against Aeromonas hydrophila infection in a crustacean, Pacifastacus leniusculus. J. Biol. Chem. 2007, 282, 33593-33598.

93. Xu, J.; Wu, S.; Zhang, X. Novel function of QM protein of shrimp (Penaeus japonicus) in regulation of phenol oxidase activity by interaction with hemocyanin. Cell. Physiol. Biochem. 2008, 21, 473-480.

94. Li, D.-F.; Zhang, M.-C.; Yang, H.-J.; Zhu, Y.-B.; Xu, X. $\beta$-Integrin mediates WSSV infection. Virology 2007, 368, 122-132.

95. Musthaq, S.S.; Kwang, J. Oral vaccination of baculovirus-expressed VP28 displays enhanced protection against white spot syndrome virus in Penaeus monodon. PLoS One 2011, 6, e26428.

96. Rajeshkumar, S.; Venkatesan, C.; Sarathi, M.; Sarathbabu, V.; Thomas, J.; Anver Basha, K.; Sahul Hameed, A.S. Oral delivery of DNA construct using chitosan nanoparticles to protect the shrimp from white spot syndrome virus (WSSV). Fish. Shellfish Immunol. 2009, 26, 429-437.

97. Sarathi, M.; Simon, M.C.; Venkatesan, C.; Hameed, A.S.S. Oral administration of bacterially expressed VP28dsRNA to protect Penaeus monodon from white spot syndrome virus. Mar. Biotechnol. 2008, 10, 242-249.

98. Anas, A.; Philip, R.; Singh, I.S.B. Chitosan as a wall material for a microencapsulated delivery system for Macrobrachium rosenbergii (de Man) larvae. Aquac. Res. 2008, 39, 885-890.

99. Sellars, M.J.; Rao, M.; Arnold, S.J.; Wade, N.M.; Cowley, J.A. Penaeus monodon is protected against gill-associated virus by muscle injection but not oral delivery of bacterially expressed dsRNAs. Dis. Aquat. Org. 2011, 95, 19-30. 
100. Xu, J.; Han, F.; Zhang, X. Silencing shrimp white spot syndrome virus (WSSV) genes by siRNA. Antivir. Res. 2007, 73, 126-131.

101. Westenberg, M.; Heinhuis, B.; Zuidema, D.; Vlak, J.M. siRNA injection induces sequence-independent protection in Penaeus monodon against white spot syndrome virus. Virus Res. 2005, 114, 133-139.

102. Hartnoll, R.G. Growth. The Biology of Crustacea; Bliss, D.E., Ed.; Academic Press: New York, NY, USA,1982; pp. 111-197.

103. Botsford, L.W. Models of Growth. In Crustacean Issues: Factors in Adult Growth; Wenner, A.M., Balkema, A.A., Eds.; A.A. Balkema Publishers: Boston, MA, USA, 1985; Volume 3, pp. 171-188.

104. Aiken, D.E.; Waddy, S.L. The growth-process in crayfish. Rev. Aquat. Sci. 1992, 6, 335-381.

105. Curtis, M.C.; Jones, C.M. Observations on monosex culture of redclaw crayfish Cherax quadricarinatus von Martens (Decapoda: Parastacidae) in earthen ponds. J. World Aquac. Soc. 1995, 26, 154-159.

106. Sagi, A.; Milstein, A.; Eran, Y.; Joseph, D.; Khalaila, I.; Abdu, U.; Harpaz, S.; Karplus, I. Culture of the Australian redclaw crayfish (Cherax quadricarinatus) in Israel, II. second growout season of overwintered populations. Isr. J. Aquac. Bamidgeh 1997, 49, 222-229.

107. Kuris, A.M.; Ra'anan, Z.; Sagi, A.; Cohen, D. Morphotypic differentiation of male Malaysian giant prawn, Macrobrachium rosenbergii. J. Crustac. Biol. 1987, 7, 219-237.

108. Sagi, A.; Ra'anan, Z.; Cohen, D.; Wax, Y. Production of Macrobrachium rosenbergii in monosex population: Yield characteristics under intensive monoculture conditions in cages. Aquaculture 1986, 51, 265-275.

109. Nair, C.M.; Salin, K.R.; Raju, M.S.; Sebastian, M. Economic analysis of monosex culture of giant freshwater prawn (Macrobrachium rosenbergii de Man): A case study. Aquac. Res. 2006, 37, 949-954.

110. Sagi, A.; Aflalo, E.D. The androgenic gland and monosex culture in prawns-A biotechnological perspective. Aquac. Res. 2005, 36, 231-237.

111. Charniaux-Cotton, H. Decouverte chez un Crustace Amphipode (Orchestia gammarella) d'une glande endocrine responsible de la differenciation des caracteres sexuels primaires et secondaires males. C. R. Acad. Sci. Paris 1954, 239, 780-782.

112. Okumura, T.; Hara, M. Androgenic gland cell structure and spermatogenesis during the molt cycle and correlation to morphotypic differentiation in the giant freshwater prawn, Macrobrachium rosenbergii. Zool. Sci. 2004, 21, 621-628.

113. Sagi, A.; Cohen, D. Growth, maturation and progeny of sex-reversed Macrobrachium rosenbergii males. World Aquac. 1990, 21, 87-90.

114. Sagi, A.; Snir, E.; Khalaila, I. Sexual differentiation in decapod crustaceans: Role of the androgenic gland. Invertebr. Reprod. Dev. 1997, 31, 55-61.

115. Touir, A. Donnees nouvelles concernant l'endocrinologie sexuelle des Crustaces Decapodes Natantia hermaphrodites et gonochoriques. II. Maintien des gonies et evolution des gametogeneses in vivo et in vitro. C. R. Acad. Sci. 1977, 284, 2515-2518.

116. Taketomi, Y.; Murata, M.; Miyawaki, M. Androgenic gland and secondary sexual characters in the crayfish Procambarus clarkii. J. Crustac. Biol. 1990, 10, 492-497. 
117. Manor, R.; Aflalo, E.D.; Segall, C.; Weil, S.; Azulay, D.; Ventura, T.; Sagi, A. Androgenic gland implantation promotes growth and inhibits vitellogenesis in Cherax quadricarinatus females held in individual compartments. Invertebr. Reprod. Dev. 2004, 45, 151-159.

118. Cui, Z.X.; Liu, H.; Lo, T.S.; Chu, K.H. Inhibitory effects of the androgenic gland on ovarian development in the mud crab Scylla paramamosain. Comp. Biochem. Physiol. A Mol. Integr. Physiol. 2005, 140, 343-348.

119. King, D.S. Fine structure of the androgenic gland of the crab, Pachygrapsus crassipes. Gen. Comp. Endocrinol. 1964, 4, 533-544.

120. Awari, S.A.; Kiran, D. Histological and histochemical study of androgenic gland of Macrobrachium rosenbergii (de Man). J. Aquac. Trop. 1999, 14, 101-112.

121. Sun, P.S.; Weatherby, T.M.; Dunlap, M.F.; Arakaki, K.L.; Zacarias, D.T.; Malecha, S.R. Developmental changes in structure and polypeptide profile of the androgenic gland of the freshwater prawn Macrobrachium rosenbergii. Aquac. Int. 2000, 8, 327-334.

122. Martin, G.; Sorokine, O.; Moniatte, M.; Bulet, P.; Hetru, C.; van Dorsselaer, A. The structure of a glycosylated protein hormone responsible for sex determination in the isopod, Armadillidium vulgare. Eur. J. Biochem. 1999, 262, 727-736.

123. Okuno, A.; Hasegawa, Y.; Ohira, T.; Katakura, Y.; Nagasawa, H. Characterization and cDNA cloning of androgenic gland hormone of the terrestrial isopod Armadillidium vulgare. Biochem. Biophys. Res. Commun. 1999, 264, 419-423.

124. Manor, R.; Weil, S.; Oren, S.; Glazer, L.; Aflalo, E.D.; Ventura, T.; Chalifa-Caspi, V.; Lapidot, M.; Sagi, A. Insulin and gender: An insulin-like gene expressed exclusively in the androgenic gland of the male crayfish. Gen. Comp. Endocrinol. 2007, 150, 326-336.

125. Chung, J.S.; Manor, R.; Sagi, A. Cloning of an insulin-like androgenic gland factor (IAG) from the blue crab, Callinectes sapidus: Implications for eyestalk regulation of IAG expression. Gen. Comp. Endocrinol. 2011, 173, 4-10.

126. Mareddy, V.R.; Rosen, O.; Thaggard, H.B.; Manor, R.; Kuballa, A.V.; Aflalo, E.D.; Sagi, A.; Paterson, B.; Elizur, A. Isolation and characterization of the complete cDNA sequence encoding a putative insulin-like peptide from the androgenic gland of Penaeus monodon. Aquaculture 2011, 318, 364-370.

127. Ventura, T.; Aflalo, E.D.; Weil, S.; Kashkush, K.; Sagi, A. Isolation and characterization of a female-specific DNA marker in the giant freshwater prawn Macrobrachium rosenbergii. Heredity 2011, 107, 456-461.

128. Stein, A.J.; Rodriguez-Cerezo, E. International trade and the global pipeline of new GM crops. Nat. Biotechnol. 2010, 28, 23-25.

(C) 2013 by the authors; licensee MDPI, Basel, Switzerland. This article is an open access article distributed under the terms and conditions of the Creative Commons Attribution license (http://creativecommons.org/licenses/by/3.0/). 